\title{
Faktor-Faktor Yang Mempengaruhi Pelayanan Pernikahan Pada Kantor Urusan Agama (KUA) Kecamatan Koto Tangah Di Kota Padang
}

\author{
Visanola Enggrita $R$ \\ Program Magister Manajemen STIE KBP Padang \\ visanolaenggrita@yahoo.co.id
}

\begin{abstract}
The religious affairs office is are afficial state institution assigned to carry out past of duties of the Indoensian religious ministry of fice in the districts and munici palities in the field of Islamic religious affairs withen the sub-diskrict. One of the main tasks held by the office religious affairs is addressing the issue of marrege registration. Is the man duty of the office of religious affairs because the ministry is very big influence in fostering religious life. There fore need to know the level of service ferformed by KUA Subdistricy Koto Tagah Padag of City. Paln the reseach is to state and analyze the factors that affect the service of recording marriage in KUA subdiskrict Koto Tangah In Padang City.The method used I study is Qualitative research with the type of correlational research or the can be called research associtional research. Population in this the marriage even to 2017 in KUA subdistrict Koto Tangah Padang City as many as 100 people. Data type used in this research is priary data and secondary data. Data collection technique is done by spreading questionnaire and documentation, while by data analysis used is descriptive analysis and multiple regression analysis.Based on the results is of $F$ test analusis and $t$ test it is professionalism, work environment and counsulting together affect the service of marriage in KUA Koto Tangah Padang City in partial. Professionalism of employees, work unvironment counseling program positively and significantly influence on service I KUA Koto Tangah Padang City.
\end{abstract}

Keywork: Fakctors Affecting the Service of Marriage

\section{PENDAHULUAN}

Undang-undang Nomor 23 Tahun 2014 tentang Pemerintahan Daerah membawa frekuensi besar dalam penyelenggaraan pemerintahan baik di tingkat pusat maupun daerah. Maka setiap Pemerintahan Kabupaten/Kota memiliki kewenangan untuk mengatur rumah tangganya sendriri tanpa ada campur tangan dari pemerintah pusat. Dengan demikian Kabupaten/Kota memperoleh hak otonomi daerah yang seluasluasnya untuk meningkatkan dan memajukan daerah masing-masing berdasarkan potensi yang ada di daerah tersebut. Hal ini dimaksudkan agar kinerja penyelenggaraan pemerintahan daerah tetap sejalan dengan tujuan nasional dalam kerangka Nasional Kesatuan Republik Indonesia.

Undang-undang Nomor 1 Tahun 1974 tentang Perkawinan pada Pasal 2 Ayat 2 menyatakan "Tiap-tiap perkawinan dicatat menurut peraturan perundang-undangan yang berlaku". Berdasakan Pasal 12 UU Nomor 1 Tahun 1974 tentang perkawinan dan direalisasikan dalam Pasal 3 sampai dengan Pasal 13 PP Nomor 9 Tahun 1975. 
Maka setiap calon pengantin wajib mencatatkan pernikahan mereka untuk mendapatkan akta nikah di dalam adiministrasi kependudukan. Pentingnya calon penganten mencatatkan pernikahannya dikarenakan akan banyak memberikan manfaat yang membawa akibat hukum bagi seseorang, misalnya untuk kepentingan waris, menentukan dan memastikan bahwa mereka adalah muhrimnya, atau dapat memberi arah ke pengadilan dimana seseorang akan bercerai dan lain sebagainya. Keberadaan Kantor Urusan Agama (KUA) merupakan bagian dari instansi pemerintah daerah yang bertugas memberikan pelayanan kepada masyarakat. Sebagai ujung tombak pelaksanaan tugas umum pemerintahan, khususnya di bidang urusan agama. Kantor Urusan Agama (KUA) menyelenggarakan pelayanan yang maksismal, manajemen kearsipan, administrasi surat menyurat dan statistik serta dokumentasi yang mandiri seperti hal yang diungkapkan oleh Moenir (2006:27), pelayanan pada hakekatnya adalah serangkaian kegiatan, karena itu merupakan proses, pelayanan berlangsung secara rutin dan berkesinambungan, meliputi seluruh kehidupan orang dalam masyarakat. Selanjutnya, pegawai atau aparatur pegewai sipil dan pegawai lainya harus memiliki etos kerja, integritas, kemampuan berinteraksi yang baik dengan semua elemen masyarakat. Sama halnya seperti instansi yang lain, Kantor Urusan Agama KotoTangah Padang sebagai pemberi layanan juga dituntut untuk memberikan pelayanan yang memuaskan kepada masyarakat salahsatunya pada pengurusan pernikahan. Berdasarkan data dari pelayan pernikahan yang dilakukan di kantor urusan agama pada tahun 2017 terhitunag bulan januari sampai Juli sebanyak 805 orang. Dengan rincian dapat dilihat pada table berikut:

Tabel 1

Rekap Jumlah Pengurusan Pernikahan

\begin{tabular}{|l|l|l|l|l|l|l|l|}
\hline \multicolumn{1}{|c|}{ Bulan } & Januari & Feb & Mar & April & mei & Juni & Jul \\
\hline $\begin{array}{l}\text { Jumlah data } \\
\text { pengurusan }\end{array}$ & 122 & 101 & 117 & 132 & 110 & 34 & 189 \\
\hline
\end{tabular}

Sumber data: Sekretariat KUA Kec. Koto Tangak

Dari tabel 1 diatas dapat diketahui jumlah kegeitan pelayanan pernikahan di KUA Kecamatan Koto Tangah Kota Padang. Dilihat dari jumlah setipa bulan pelayan tersebut cukup memberikan informasi bahwa pelayanan pernikahan masih dalam menimal. Selain data tersebut mengenai hal factor dalam pelayan pernikahan, berdasarkan hasil wawancara dengan masyarkat bahwa masih banyak masyakrakat yang tidak mencatatkan pernikahannya di KUA Kecamatan Koto Tangah Kota Padang. Selain itu masih ada masyarkat yang melakukan pristiwa perkawinan diluar prosedur Kantor Urusan Agama Koto Tangah Kota Padang. Dengan demikina perlu inovasi atau gerakan pasti dalam memberikan pelayanan kepada masyarakat agar maksimal dan sesuai dengan misi KUA Kecamatan Koto Tangah Padang. Agar pelayanan maksimal diperlukan faktor pendukung. Factor pendukung baik berupa sumber daya manusia, lingkungan kerja dan rancangan program atau kegiatan penyuluhan yang dilakkukan oleh pegewai. Sastrohadiwiryo (2005: 177) mengartikan bahwa makna lingkungan kerja sangat berpengaruh besar terhadap efektifitas kerja dan orientasi. Oleh karenanya maka lingkungan kerja akan memberikan suasana baru bagi dirinya yang akan membawa pengaruh terhadap keberhasilan pelaksanaan tugas 
dan pekerjaannya. Selanjutnya menurut Sedarmayati (2009:1) lingkungan kerja merupakan kseluruhan alat perkakas dan bahan yang dihadapi, lingkungan sekitarnya dimana seseorang bekerja, metode kerjanya, serta pengaturan kerjanya baik sebagai perseorangan maupun sebagai kelompok. Dapat disimpulkan bahwa lingkungan kerja merupakan segala sesuatu yang ada disekitar pegawai pada saat bekerja, baik berbentuk fisik atau non fisik, langsung atau tidak langsung, yang dapat mempengaruhi dirinya dan pekerjaannya saat bekerja. Factor lain dari lingkunga kerja adalah profesionalitas pegeawai. Pandji (2006:69) menjelaskan bahwa dalam Kamus Webster Amerika menegaskan bahwa profesionalisme adalah suatu tingkah laku, suatu tujuan atau rangkaian kualitas yang menandai atau melukiskan coraknya suatu "profesi". Profesionalisme mengandung pula pengertian menjalankan suatu profesi untuk keuntungan atau sumber penghidupan (The following of a profession for gain or livelihood).

Oleh karena itu, dari latar belakang di atas peneliti melakukan penelitian untuk mengetahui dan mendskripsikan secara ilmiah danlebih mendalam mengenai masalah faktor-faktor pelayanan pencatatan nikah yang diberikan oleh Kantor Urusan Agama (KUA) Kecamatan Koto Tangah Padang. Penelitian yang berjudul" Faktor-Faktor Yang Mempengaruhi Pelayanan Pernikahan Pada Kantor Urusan Agama (KUA) Di Kecamatan Koto Tangah Kota Padang. Dengan tujuan untuk mengetahui Pengaruh lingkungan kerja, Pengaruh porfesionalitas pegawai terhadap pelayanan pernikahan di KUA Koto Tangah Kota Padang, Program penyuluhan mempengaruhi terhadap peyalanan pernikahan di KUA Kecamatan Kota Tangah Kota Padang, dan Pengaruh lingkungan kerja, profesionalitas pegawai terhadap pelayanan pernikahan di KUA Koto Tangah Kota Padang. Secara lebih jelasnya dapat dilihat pada kerangka konseptual berikut:

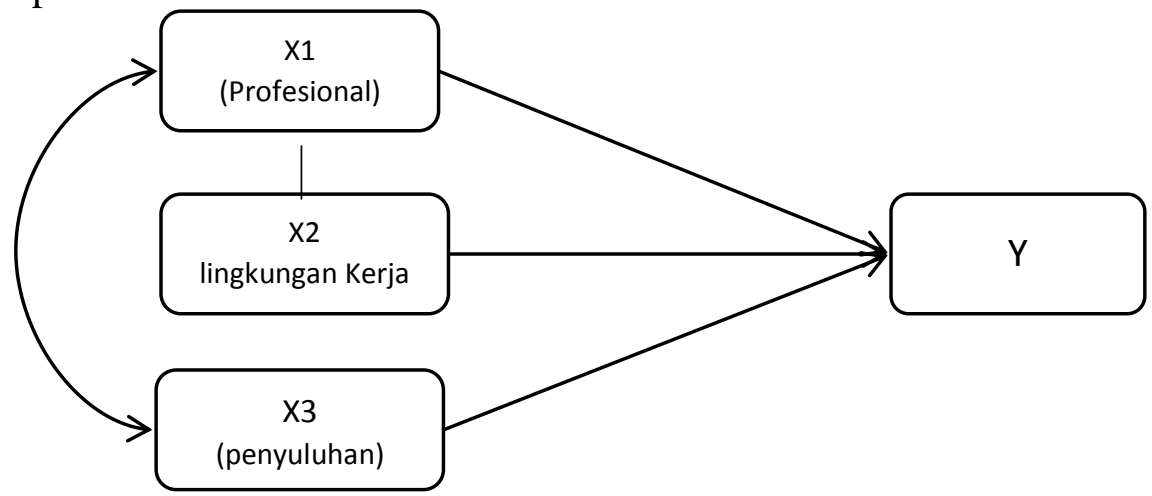

\section{Gambar 1. Kerangka Konseptual}

\section{Metode Penelitian}

Berdasarkan rumusan, tujuan dan hipotesis penelitian maka metode yang digunakan dalam penelitian ini adalah penelitian kuantitatif dengan jenis penelitian korelasional atau yang dapat disebut dengan penlitian associational research. Penelitian korelasional adalah suatu tipe penelitian yang melihat hubungan antara satu peubah dengan satu atau beberapa peubah yang lain (A. Muri. 2015. hal: 64). Sama hal yang diungkapkan oleh Sumadi (2015. hal: 82) bahwa" penelitian korelasional bertujuan untuk menditeksi seajauhmana variasi-variasi pada suatu faktor berkaitan dengan variasi-variasi pada satu atau lebih faktor lain berdasarkan pada koefisien korelasi. Dari uraian pendapat ahli 
tersebut maka penelitian ini menganalisis hubungan antara lingkungan kerja, porfesionalitas pegawai, dan program penyuluhan pengaruhinya pada pelayanan pernikahan. Populasi dalam penelitian ini adalah Masyarakat yang sudah melakukan peristiwa pernikahan pada tahun 2017 di KUA Kecamatan Koto Tangah. Jumlah peristiwa pernikahan pada tahun 2017 sebagai berikut:

Tabel 2

Jumlah Pristiwa Pernikahan

\begin{tabular}{|l|l|l|l|l|l|l|l|l|}
\hline Bulan & Januari & $\begin{array}{l}\text { Februa } \\
\text { ri }\end{array}$ & $\begin{array}{l}\text { Mare } \\
\mathbf{t}\end{array}$ & April & Mei & Juni & Juli & Jml Total \\
\hline Jumlah & 122 & 101 & 117 & 132 & 110 & 34 & 189 & 805 \\
\hline
\end{tabular}

Dari jumlah populasi yang ada maka yang dijadikan sampel penilitan adalah dalam penelitian ini adalah masyarakat yang melakukan pengurusan pernikahan di KUA Kecamatan Koto Tangah. Teknik dalam pengambilan sampel ini menggunakan teknik kuota sampling (sampling kuota). Teknik menentukan sampel sesuai dengan kuata yang dinginkan. Sampel yang diambil adalah yang melakukan prestiwa pernikahan pada bulan juni dan juli peratahun 2017. Pengamabilam sampel dilakukan secara acak dalam sistem kuata sampel, teknnik ini digunakan karena wilayah populasi terlalu luas. Menurut Sugiyono (2012. hal: 124) teknik sampling daerah digunakan untuk menetukan sampel bila obyek yang akan diteliti atau sumber data sangat luas. Jenis data pada penelitian ini adalah berupa data kuantitatif dan kualitatif. Data kulaitatif berupa hasil wawancara. Sedangkan data kuantitatif adalah data dari hasil angket yang diberikan kepada sampel penelitian.Instrumen peneitian adalah lembar angket atau kuesioner dan lembar wawancara. Instrumen dijabarkan berdasarkan indikator penelitian yakni:

Tabel 3

Indikator Penelitian

\begin{tabular}{|c|c|c|c|}
\hline Variabel penelitian & Indikator & $\begin{array}{l}\text { Jumlah } \\
\text { Soal }\end{array}$ & No Soal \\
\hline \multirow{4}{*}{$\begin{array}{l}\text { Profesionalitas } \\
\text { Pegawai }\end{array}$} & 1. Kecakapan & 3 & $2,4,5$ \\
\hline & 2. Disiplin & 4 & $1,6,7,10$ \\
\hline & $\begin{array}{l}\text { 3. Kemampuan untuk } \\
\text { bertindak }\end{array}$ & 3 & $9,11,12$ \\
\hline & 4. Komitmen & 2 & 3,8 \\
\hline \multirow{4}{*}{ Lingkungan Kerja } & a) Iklim kerja, & 3 & $3,9,14$ \\
\hline & b) Kerjasama, & 5 & $2,5,8,10,12$ \\
\hline & c) Sarana prasarana, & 2 & 1,6 \\
\hline & d) Keharmonisan hubungan. & 4 & $4,7,11,13$ \\
\hline \multirow{2}{*}{ Penyuluhan } & 1. Kegiatan penyuluhan & 2 & 2,3 \\
\hline & 2. Kebermanfaatan & 3 & $1,4,5$ \\
\hline \multirow{3}{*}{ Pelayanan } & Ketepatan, & 9 & $7,8,10,13,1421,24,25,30$ \\
\hline & $\begin{array}{l}\text { kermahan pegawai dan } \\
\text { Kemudahan }\end{array}$ & 6 & $11,12,18,19,2,20$ \\
\hline & Transparansi & 18 & $\begin{array}{c}1,2,3,4,5,6,15,16,17,22,23,26 \\
28,29,31,32,33\end{array}$ \\
\hline
\end{tabular}


Pengujian hipotesis dalam penelitian ini menggunakan analisis regresi ganda. Analisis regresi berganda bertujuan untuk mengetahui hubungan kausal antara variabel yang mempengaruhi dengan variabel yang dipengaruhi. Dengan model persamaan regresi berganda sebagai berikut:

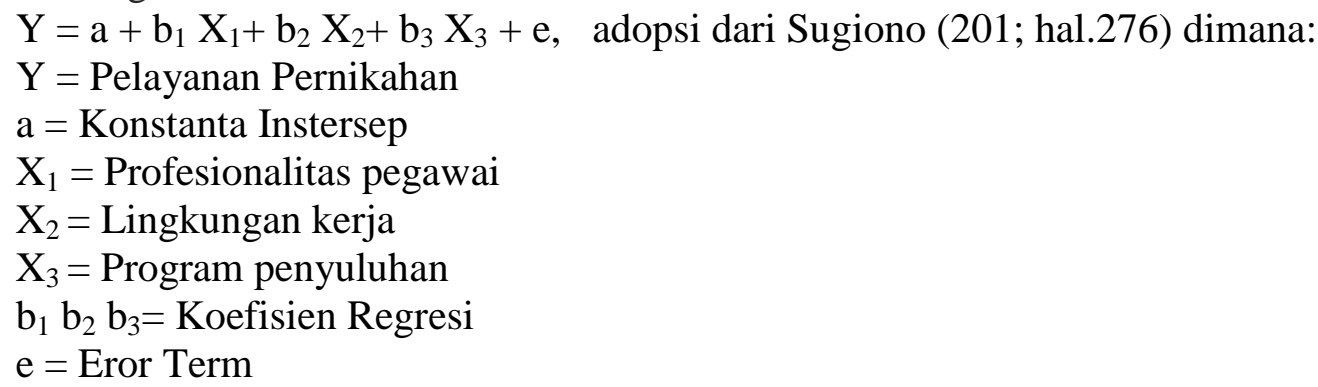

\section{Hasil dan Pembahasan}

Responden dalam penelitian ini adalah masyarakat yang berada di lingkunagan pengurusan KUA Kecamatan Koto Tangah Kota Padang. Masyarakat yang dimaksud adalah masyarakat yang pernah mengurus administrasi pernikahan dan melangsungkan penikahan. Masyarakat yang menjadi responden dipilih secara acak. Pengambilan informasi dari Masyarakat selaku responden dalam penelitain ini dilakukan dengan penyebaran atau angket. Angket yang disebarkan sebanyak 100 angket, namun yang kembali hanya 90 angket dari responden. Hal ini terjadi karnena beberap faktor dari responden yang tidak bisa diuraikan secara ditail.

Hasil dalam penelitian ini menguruaikan tentang faktor lingkungan, profesionalitas pegawai, program penyuluhan, dan pelayan pernikahan KUA Kecamatan Koto Tangah Kota Padang. Hasil penelitian ini berdasarkan hasil intrumen yang diberikan kepada responden yang berjumlah 90 responden. Secara umum hasil penelitian ini dapat terlihat pada tabel berikut:

Tabel 4

Distribusi Variabel Penelitian

\begin{tabular}{|c|c|c|c|c|c|}
\hline Variabel & $\begin{array}{c}\text { Jumlah } \\
\text { responden }\end{array}$ & $\begin{array}{c}\text { Jumlah } \\
\text { Item } \\
\text { Pertayaan }\end{array}$ & $\begin{array}{c}\text { Rata-rata } \\
\text { Skor }\end{array}$ & $\begin{array}{c}\text { TCR } \\
(\%)\end{array}$ & Ket \\
\hline Lingkungan Kerja & 90 & 14 & 4.3103 & 86.20 & $\begin{array}{c}\text { Sangat } \\
\text { baik }\end{array}$ \\
\hline $\begin{array}{c}\text { Profesionalitas } \\
\text { Pegawai }\end{array}$ & 90 & 12 & 4.3311 & 86.11 & $\begin{array}{c}\text { Sangat } \\
\text { baik }\end{array}$ \\
\hline Program Penyuluhan & 90 & 5 & 4,04 & 86.622 & $\begin{array}{c}\text { Sangat } \\
\text { baik }\end{array}$ \\
\hline Pelayan & 90 & 33 & 4.1774 & 83.54 & $\begin{array}{c}\text { Sangat } \\
\text { baik }\end{array}$ \\
\hline
\end{tabular}

Berdasakan tabel terlihat bahwa pelayanan pegawai KUA Koto Tangah Kota Padang dengan rata-rata 4,1 dan presentase $83,54 \%$ ini menunjukan pelayanan pegawai dalam kategori sangat baik berdasarakan kriteria pada bab III tabel 3.4. Hal ini didukung atas program penyuluhan, profesionalitas pegawai dan lingukngan kerja sangat mendukung program pelayan. 


\section{Uji t}

Uji t digunakan untuk mengetahui apakah variabel-variabel independen secara parsial berpengaruh nyata atau tidak terhadap variabel dependen. Derajat signifikansi yang digunakan adalah 0,05. Apabila nilai signifikan lebih kecil dari derajat kepercayaan maka kita menerima hipotesis alternatif dan sebaliknya atau apabila $\mathrm{t}$ hitung $>\mathrm{t}$ kritis maka hipotesis nol (Ho) ditolak dan apabila $\mathrm{t}$ hitung $<\mathrm{t}$ kritis maka hipotesis nol (Ho) diterima. Selanjutnya yang menyatakan bahwa suatu variabel independen secara parsial mempengaruhi variabel dependen. Outputnya sebagai berikut;

Tabel 5

Uji t

\begin{tabular}{|ll|r|rr|}
\hline & & & & \\
Model & & $\mathrm{t}$ & \multicolumn{2}{c|}{ Sig. } \\
\hline 1 & (Constant) & & 6.867 & .000 \\
& Lingkungan Kerja & .909 & .366 \\
& Profesionalitas Pegawai & 1.420 & .159 \\
& Program Penyuluhan & .241 & .810 \\
\hline
\end{tabular}

a. Dependent Variable: Pelayanan

Berdasarkan tabel 4.10 dapat diketahui hasil pengaruh setiap variabel bebas terhadap variabel terikat yakni:

1) Pengaruh Lingkungan kerja terhadap pelayanan pernikahan di KUA Koto Tangah Kota Padang

Dari hasil analisis yang terdpat pada tabel 4.9 diatas terdapat bahwa nilai sig nifikan sebsar 0,366 $>\alpha 0,05$ dan nili thitung 0,909 lebih kecil dari t tabel (2). Hal ini sesuai kriteria yang dijelaskan oleh Riduwan $(2011 ; 128)$ bahwa jika $-\mathrm{t}_{\text {tabel }} \leq \mathrm{t}_{\text {hitung }} \geq$ $+\mathrm{t}_{\text {tabel }}$ dan jika $\alpha=0,05$ lebih kecil atau sama dengan nilai Sig $(0,05)$ maka $\mathrm{H}_{0}$ diterima dan $\mathrm{H}_{\mathrm{a}}$ ditolak. Hal yang sama juga dinyatakan oleh Sugiyono $(2013 ; 124)$ dan

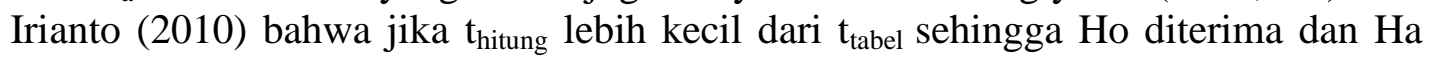
ditolak. Dengan demikian lingkungan kerja pegawai mempunyai pengaruh terhadap pelayanan di Kantor KUA Kecamatam Koto Tangah Kota Padang.

2) Pengaruh porfesionalitas pegawai terhadap pelayanan pernikahan di KUA Koto Tangah Kota Padang

Dari hasil analisis yang terdpat pada tabel 4.5 diatas terdapat bahwa nilai sig nifikan sebsar $0,159>\alpha 0,05$ dan nili thitung 1,420 lebih kecil dari t tabel (2). Hal ini sesuai kriteria yang dijelaskan oleh Riduwan $(2011 ; 128)$ bahwa jika $-\mathrm{t}_{\text {tabel }} \leq \mathrm{t}_{\text {hitung }} \geq$ $+\mathrm{t}_{\text {tabel }}$ dan jika $\alpha=0,05$ lebih kecil atau sama dengan nilai $\operatorname{Sig}(0,05)$ maka $\mathrm{H}_{0}$ diterima dan $\mathrm{H}_{\mathrm{a}}$ ditolak. Hal yang sama juga dinyatakan oleh Sugiyono $(2013 ; 124)$ dan

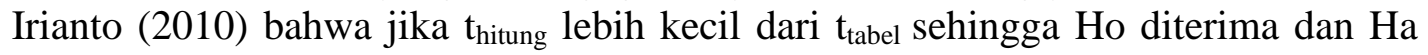
ditolak. Dengan demikian profesioalitas pegawai mempunyai pengaruh terhadap pelayan di Kantor KUA Kecamatam Koto Tangah Kota Padang. 
3)Pengaruh program penyuluhan terhadap pelayanan pernikahan di KUA Koto Tangah Kota Padang

Berdasarkan tabel diatas diperoleh nilai sig 0.810>0,05 dan nili $t_{\text {hitung }} 0,241$ lebih kecil dari t tabel (2). Dengan demikian dapat diartikan bahwa program penyuluhan memberikan pengaruh terhapat pelayanan yang dilakukan oleh pegawai Kantor KUA Kecamatam Koto Tangah Kota Padang.

\section{Uji F}

Uji F dilakukan untuk menguji apakah secara bersama variabel independen mampu menjelaskan variabel dependen secara baik. Uji ini untuk mengetathui seberapa besar pengaruh lingkungan kerja, profesionalitas pegawai dan program penyuluhan terhadap pelayanan pernikahan di KUA Koto Tangah Kota Padang. Acuan yang digunakan adalah dengan membandingkan nilai signifikansi. Hasil analisis daat dilihat pada tabel 4.1 berikut:

\section{Tabel 6}

Uji F

ANOVA $^{\text {D }}$

\begin{tabular}{|rl|r|r|r|r|r|}
\hline Model & & Sum of Squares & df & Mean Square & F & Sig. \\
\hline 1 & Regression & 1.505 & 3 & .502 & 3.887 & $.012^{\mathrm{a}}$ \\
& Residual & 11.102 & 86 & .129 & & \\
& Total & 12.607 & 89 & & & \\
\hline
\end{tabular}

a. Predictors: (Constant), Program Penyuluhan, Lingkungan Kerja, Profesionalitas Pegawai

b. Dependent Variable: Pelayanan

Dari Tabel bahwa nilai F hitung diperoleh 3,887 > table (1,5) dan nilai Sig. yang didapat sebesar 0.012(<0,05). Berdasarkan hasil uji $\mathrm{F}$ tersebut, maka variabel independen secara bersama-sama memberikan pengaruh yang signifikan terhadap variabel dependen. Jadi, dapat diartikan bahwa profesionalitas, lingkungan kerja dan penyuluhan secara bersama-sama berpengaruh terhadap pelayanan pernikahan di KUA Koto Tangah Kota Padang.

\section{Pembahasan}

1. Pengaruh Lingkungan kerja terhadap pelayanan pernikahan di KUA Koto Tangah Kota Padang

Lingkungan kerja adalah kehidupan sosial, psikologi, dan fisik dalam perusahaan yang berpengaruh terhadap pekerja dalam melaksanakan tugasnya. Demikian pula halnya selama melakukan pekerjaan, setiap pegawai akan berinteraksi dengan berbagai kondisi yang terdapat dalam lingkungan kerja. Lingkungan kerja merupakan salah satu faktor yang mempengaruhi kinerja seorang pegawai. Seorang pegawai yang bekerja di lingkungan kerja yang mendukung dia untuk bekerja secara optimal akan menghasilkan kinerja yang baik yakni memberikan pelayanan yang baik bagai masyarakat, sebaliknya jika seorang pegawai bekerja dalam lingkungan kerja yang tidak memadai dan tidak mendukung untuk bekerja secara optimal akan membuat pelayanan akan lebih rendah karena menurut Moenir (2006:27), pelayanan pada hakekatnya adalah serangkaian kegiatan, karena itu merupakan proses, pelayanan berlangsung secara rutin dan berkesinambungan, meliputi seluruh kehidupan orang dalam masyarakat. 
Intinya memberikan yang terbaik buat masyrakat yang dilayani. Sesuai apa yang diungkapkan oleh Ishak dan Tanjung (2003), bahwa lingkungan kerja menciptakan gairah kerja, sehingga produktivitas dan prestasi kerja meningkat. Ngan deikina akan beraitan antara lingkungan kerja dengan pelayanan yang diterima oleh masyarakat. Berdasarkan analisis dapat disimpulkan bahwa lingkungan kerja mempunyai pengaruh yang signifikan terhadap pelayanan pegawai KUA Kecamatan Koto Tangah Padang. Hal ini terlihat dari nilai sig nifikan sebsar 0,366 $>\alpha 0,05$. dan nili $t_{\text {hitung }}$ 0, 909 lebih kecil dari t tabel (2). Dengan demikian lingkungan kerja pegawai mempunyai pengaruh terhadap pelayan di kantor KUA Kecamatam Koto Tangah Kota Padang. Lebih lanjut Yusuf (2002 : 86) menjelaskan bahwa keberhasilan seseorang dalam melakukan pekerjaan akan tercipta kalau didukung oleh lingkungan kerja, lingkungan keluarga, lingkungan masyarakat, sosial ekonomi dan budaya organisasi yang baik, kooperatif, suportif dan menyenangkan.

2. Porfesionalitas pegawai terhadap pelayanan pernikahan di KUA Kecamatan Koto Tangah Kota Padang

Profesional adalah pekerjaan atau kegiatan yang dilakukan oleh seseorang dan menjadi sumber penghasilan kehidupan yang memerlukan keahlian, kemahiran, atau kecakapan yang memenuhi standar mutu atau norma tertentu serta memerlukan pendidikan dan latihan dalam profesi. Berasrakan hasil penelitian yang dilakukan oleh Yeyen Suci Hardiyanti, dkk (2017) menunjukkan bahwa profesionalisme pegawai mempunyai pengaruh yang kuat terhadap kualitas pelayanan pada kantor Dinas Kependudukan dan Catatan Sipil Kota Kendari. Dengan demikian hasil penelitian ini juga membuktikan bahwa profesionlaitas mempengarui terhdapa pelayan yang diberikan oleh pegwai di KUA Kecamatan Koto Tangah Padang. Hal ini dapat terlihat berdasarkan analisis bahwa nilai sig nifikan sebsar 0,159> $>0,05$ dan nili $\mathrm{t}_{\text {hitung }}$ 1,420 lebih kecil dari $\mathrm{t}$ tabel (2). Dengan demikian profesioalitas pegawai mempunyai pengaruh terhadap pelayan di kantor KUA Kecamatam Koto Tangah Kota Padang. Senada dengan apa yang diteukan oleh Nur Cahyani (2007) yakni mengindikasikan bahwa untuk meningkatkan kinerja karyawan pada kantor pajak di Semarang, kantor pajak perlu memperhatikan faktor-faktor seperti profesionalisme pemeriksa pajak, kepuasan kerja, dan komitmen organisasi karena faktor-faktor tersebut terbukti mempengaruhi tinggi rendahnya kinerja karyawan. Hal ini juga sama dengan apa yang dilakukan oleh pegawai terhadap tugasnya yang emberikan pelayanan kepada masyarakat. Hal yang sama juga dibuktikan berdasarkan hasil penelitian yang dilakukan oleh Andila Mandasari, 2014 diperoleh hasil bahwa profesionalisme pegawai mempunyai pengaruh yang kuat dan bernilai positif serta signifikan terhadap kualitas pelayanan. Artinya apabila profesionalisme pegawai meningkat maka kualitas pelayanan pernikahan yang dihasilkan juga akan mengalami peningkatan.

3. Pengaruh program penyuluhan terhadap pelayanan Pernikahan di KUA Kecamatan Koto Tangah Kota Padang

Dilihat dari penyuluhan adalah Secara umum pengertian penyuluh agama menurut Keputusan Bersama Menteri Agama RI dan Kepala Badan Kepegawaian Negara nomor: 574 tahun 1999 dan nomor: 178 tahun 1999 tentang jabatan fungsional penyuluh agama dan angka kreditnya, menyebutkan bahwa Penyuluh 
Agama adalah Pegawai Negeri Sipil yang diberi tugas, tanggung jawab, wewenang untuk melakukan kegiatan bimbingan dan penyuluhan agama dan pembangunan melalui bahasa agama. Dengan demikian Penyuluh Agama adalah para juru penerang penyampai pesan bagi masyarakat mengenai prinsip-prinsip dan etika nilai keberagamaan yang baik. Hasil akhir yang ingin dicapai dari penyuluh agama, pada hakekatnya ialah terwujudnya kehidupan masyarakat yang memiliki pemahaman mengenai agamanya secara memadai yang ditunjukan melalui pengamalannya yang penuh komitmen dan konsistensi seraya disertai wawasan multikultur untuk mewujudkan tatanan kehidupan yang harmonis dan saling menghargai satu sama lain. Dengan demikina pemberian penyuluhan haruslah sesuai denga apa yang diamanatkan dalam agama dan peraturan. Jika peyuluhan yang tepat maka akanmebrikan kontribusi terhdapa masyarakat.

Penyuluhan yang dilakukan merupakan sebagian utama dari tugas yang dilakukan oleh pegawai KUA Kecamatan Koto Tangah Padang dengan tujuan masyrakat memahami tentang pelayan, prosedur dan bimbangan yang berhubungan terutama dengan keagmaan seprti pelayanan pernikahan. Sesuai dengan hasil penelitian yang dilakukan bahwa program penyuluhan yang dilakukan mempengaruhi terhadap pelayanan di KUA Kecamatan Koto Tongah Kota Padang. Hal ini dapt dilihat dari hasil analisis yakni nilai sig 0.810>0,05 dan nili $t_{\text {hitung }}$ 0,241 lebih kecil dari t tabel (2). Dengan demikian dapat diartikan bahwa program penyuluhan memberikan pengaruh terhapat pelayanan yang dilakukan oleh pegawai Kantor KUA Kecamatam Koto Tangah Kota Padang. Dimana, tujuan Penyuluhan yang dilakukan adalah untuk meningkatkan kwalitas umat dalam berbagai segi kehidupan dan penghidupannya baik yang bersifat lahiriyah maupun yang bathiniah.

4. Pengaruh lingkungan kerja, profesionalitas pegawai dan program penyuluhan terhadap pelayanan pernikahan di KUA Koto Tangah Kota Padang

Hasil analisis data memperlihatkan terdapat pengaruh positif dan signifikan dari lingkungan kerja, profesionalitas pegawai dan program penyuluhan terhadap pelayanan pernikahan di KUA Koto Tangah Kota Padang hal ini ditunjukn hasil uji F nilai $F$ hitung diperoleh $3,887>\operatorname{tabel}(1,5)$ dan nilai Sig sebesar $0.012(<0,05)$. Berdasarkan hasil uji $\mathrm{F}$ tersebut, maka variabel independen secara bersama-sama memberikan pengaruh yang signifikan terhadap variabel dependen. Dengan demikian bahwa lingkungan kerja, profesionalitas pegawai dan program penyuluhan terhadap pelayanan pernikahan di KUA Koto Tangah Kota Padang. Selanjutnya pengaruh varibel bebas terhadap variabel terikat dapat dilihat pada hasil yang diperoleh nilai $\mathrm{R}^{2}$ ( $\mathrm{R}$ square) sebesar .346 ${ }^{\mathrm{a}}$. Hal ini menunjukkan bahwa Lingkungan kerja, profesionalitas pegawai dan program penyuluhan secara bersama-sama berkontribusi sebesar 34,6,0\% terhadap pelayanan dan sisahnya dipengaruhi oleh faktor lain. Dari urian tersebut diatas untu memberikan pelayanan yang baik dan berkualitas terutama pada pelayan pernikahan kepada masyarkat diperlukan dukungan dari semua aspek kerja. Hal ini sama dengan apa yang diungkapan oleh Lewis dalam Tjiptono (2008:85) kualitas layanan bisa diartikan sebagai ukuran seberapa bagus tingkat layanan yang diberikan mampu sesuai ekspektasi pelanggan. 


\section{KESIMPULAN}

Berdasarkan hasil penelitian dan pembahasannya, maka dapat diambil suatu kesimpulan bahwa Terdapatnya pengaruh yang signifikan antara lingkungan kerja, profesionlisme pegawai dan program penyuluha secara bersama-sama terhadap pelayan perni kahan di KUA Kecamatan Koto Tangah Kota Padang. Profesionalisme pegawai mempunyai pengaruh yang signifikan dan bernilai positif terhadap kualitas pelayanan pernikahan pada KUA Kecamatan Koto Tangah Kota Padang. Program penyuluhan yang dilakukan oleh KUA Kecamatan Koto Tangah memberikan pengaruh tehadap pelayanan. Selanjutnya, lingkungan kerja berpengaruh positif dan signifikan terhadap pelayanan di

\section{DAFTAR PUSTAKA}

Andila Mandasari, 2014. Pengaruh Profesionalisme Pegawai Terhadap Kualitas Pelayanan Publik Pada Kantor Dinas Kependudukan Dan Catatan Sipil Kabupaten Kutai Barat eJournal Administrasi Negara, 2014, 4 (2): 1148-1158 ISSN 00000000, ejournal.an.fisip-unmul.org

Ardie Gunawan. 2015. judul penelitian Efektivitas Kerja Pegawai Dalam Upaya Peningkatan Pelayanan Publik Di Kantor Urusan Agama Kecamatan Tanjung Redeb Kabupaten Berau eJournal Ilmu Administrasi Negara, 3 (5) 2015 : 15141525 ISSN 0000-0000, ejournal.ip.fisip-unmul.ac.id (C) Copyright 2015

Arep, Ishak dan Hendri Tanjung. 2003. Manajemen Sumber Daya Manusia. Universitas Trisakti: Jakarta.

Fernos, J., \& Putra, Y. E. (2019). Analisa Pengaruh Kualitas Pelayanan Terhadap Kepuasan Nasabah Pada PT. Bank Mega Syari'ah Padang. https://doi.org/10.31219/osf.io/y2baf

Oyoh Bariah. Rekonstruksi Pencatatan Perkawinan Dalam Hukum Islam". Jurnal ilmiah Solusi Vol. 1 No. 4 Desember 2014 - Februari 2015: 20-291

Ibrahim, Amin. 2008. Teori dan Konsep Pelayanan Publik Serta Implementasinya. Mandar Maju. Jakarta.

Kurniawan, Agung. 2005 Transformasi Pelayanan Publik. Pembaruan Yogyakarta.

Marlius, D. (2018). Loyalitas Nasabah Bank Nagari Syariah Cabang Bukittinggi Dilihat Dari Kualitas Pelayanan. Jurnal Pundi. Volume 1. No. 3. Hal.12-22. https://doi.org/10.31575/jp.v1i3.60

Marlius, D. (2018). Pengaruh Dimensi Kualitas Pelayanan Website Akademik Terhadap Kepuasan Mahasiswa Pada STIE "KBP”. Jurnal Ipteks Terapan. Volume 12. No. 2. Hal. 116-128. http://doi.org/10.22216/jit.2018.v12i2.633

Marlius, D. Putriani, I. (2019). Kepuasan Nasabah PT. Bank Rakyat Indonesia Unit Tapan Cabang Painan Dilihat dari Kualitas Layanan Customer Service. Jurnal Pundi. Volume 3. No. 2. Hal.111-122. https://doi.org/10.31575/jp.v3i2.151

Marlius, D. Ananda, F. (2019). Pengaruh Kualitas Pelayanan Website Akademik Terhadap Minat Kuliah di AKBP Padang. Jurnal Pundi, Vol. 03, No. 03. Hal. 191204. https://doi.org/10.31575/jp.v3i3.190

M. Iqbal Hasan. 2011. Pokok-Pokok Materi Statistik 1 (Statistik Deskriftif). Jakarta: Bumi Aksara. 
Moenir, H.A.S. 2006. Manajemen Pelayanan Umum di Indonesia. Bumi Aksara. Jakarta.

Moh. Makmun \& Bahtiar Bagus Pribadi.2016. Efektifitas Pencatatan Perkawinan di Kantor Urusan Agama (KUA) Kecamatan Tembelang Kabupaten Jombang.; Jurnal Hukum Keluarga Islam Volume 1, Nomor 1, April 2016; ISSN: 2541-1489 (cetak)/2541-1497 (online); 16-32

Nurun Ala Nur Alifia. 2017. Dengan judul penelitian Kualitas Pelayanan Pencatatan Nikah Di Kantor Urusan Agama (Kua) Kecamatan Sukolilo Surabaya S1 Ilmu Administrasi Negara, FIS, UNESA (nurunalanuralifia@gmail.com)

Nur Cahyani. 2007. Analisis Pengaruh Profesionalisme Pemeriksa Pajak, Kepuasan

Kerja Dan Komitmen Organisasi Terhadap Kinerja Karyawan (Studi: Pada Kantor Pajak Di Wilayah Semarang) TESIS Program Studi Magister Manajemen Universitas Diponegoro

Putra, Y. E., \& Aziz, N. (2019). Pengaruh Kualitas Pelayanan Dan Kepuasan Pelanggan Terhadap Loyalitas Nasabah PT. Bank Rakyat Indonesia Cabang Padang. https://doi.org/10.31219/osf.io/hcsw2

Riduwan. 2012. Dasar-Dasar Statistika. Bandung: Alfabeta.

Santosa, Pandji. 2008. Administrasi Publik, Teori dan Aplikasi Good Governance. Refika Aditama. Bandung.

Sastrohadiwiryo. 2005. Manajemen Tenaga kerja Indonesia (pendekatan administrative dan operasional), Cetakan ketiga. Bumi Aksara, Jakarta

Sedarmayanti. 2000. Restrukturisasi dan Pemberdayaan Organisasi untuk Menghadapi Dinamika Perubahan Lingkungan. Mandar Maju. Bandung.

Sugiyono. 2005. Metode Penelitian Administrasi. Rineka Cipta. Jakarta.

Susanti, F. W Ekazaputri. (2018). Service Performance Dan Kepuasan Sebagai Moderating Variabel Terhadap Loyalitas Nasabah Pada PT BPR Labuh Gunung Payakumbuh Jurnal Benefita: Ekonomi Pembangunan Manajemen Bisnis Dan Akuntansi. Volume 3. No. 3. Hal. 433-444.http://doi.org/10.22216/jbe.v3i3.3472

Tiza, M. F., \& Susanti, F. (2019). Pengaruh Kualitas Pelayanan Terhadap Kepuasan Pelanggan, Studi kasus pada perusahaan JNE Cabang Padang. https://doi.org/10.31227/osf.io/hx87m

Timpe A. Da1e.2000. Seri Manajemen SDM Kinerja, Gramedia, Jakarta,

Yusuf, A. Muri.2002. Kiat Sukses Dalam Karir, Ghalia Indonesia, Jakarta.

Yeyen Suci Hardiyanti, Gunawan, Dan Asriani. 2017 Pengaruh Profesionalisme Pegawai Terhadap Kualitas Pelayanan Publik Pada Kantor Dinas Kependudukan Dan Catatan Sipil Kota Kendari”. Hasil Penelitian Jurusan Ilmu Administrasi Program Studi Ilmu Administrasi Negara Fakultas Ilmu Administrasi Universitas Halu Oleo

Undang-undang Dasar Republik Indonesia 1945 Amandemen I, II, III, IV. 2002. Penabur Ilmu. Jakarta.

Undang-undang Nomor 1 Tahun 1974 tentang Perkawinan.

Undang-undang Nomor 23 Tahun 2014 tentang Pemerintahan Daerah.

Undang-undang Pelayanan Publik No. 25 Tahun 2009. New Merah Putih. Jakarta. 